\title{
Spatial Modelling and Spread of Corn Stunt and Maize Bushy Stunt in Corn Hybrids (Zea mays)
}

\section{Érica de Castro Costa*, Walter Baida Garcia Coutinho, Cleberly Evangelista dos Santos, Flavia Maria dos Santos, Karolinny de Souza Almeida, Rafaela Souza Alves Fonseca and Milton Luiz Da Paz Lima}

Instituto Federal Goiano, Campus Urutaí, Urutaí, GO, Brasil

*Corresponding Author: Érica de Castro Costa, Instituto Federal Goiano, Campus Urutaí, Urutaí, GO, Brasil.

Received: June 06, 2019; Published: July 12, 2019

DOI: 10.31080/ASAG.2019.03.0573

\begin{abstract}
In recent years, there have been growth in number in the outbreaks of Maize Corn Stunt and "Maize Bushy Stunt Phytoplasma" incidence in maize (Zea mays) crops, probably due to the increase in the spittle population. The objective was to perform a modelling and evaluate the spatial distribution of corn stunt and "Maize Bushy Stunt Phytoplasma" in different commercial maize hybrids grown in the 2017 harvest. The experiment was carried out with 13 hybrids in the city of Ipameri, Goiás state, Brazil. The experimental area per hybrid showed the dimensions of $4 \times 70 \mathrm{~m}$ and $10 \mathrm{~m}$ in length, resulting in a population of plants organized in a spacing of $0.5 \mathrm{~m}$ and distance between plants of $0.2 \mathrm{~m}$ sown in eight growing lines. The lines were referenced in the $\mathrm{X}$ and $\mathrm{Y}$ axis, with the corn stunt and "Maize Bushy Stunt Phytoplasma" incidence, referenced by Z in a useful area per hybrid of $210 \mathrm{~m}^{2}$ for modelling and construction of spatial distribution maps. There was a significant difference between the geographic distance and the incidence of both types of corn stunt. The adjustment models recognized for corn stunt and "Maize Bushy Stunt Phytoplasma" by cultivar were Spherical, Exponential, Linear and Gaussian, being the which spherical is the best model to explain the spatial distribution of both fodder was Keywords: Dalbulus maidis; Epidemiology; Phytoplasma; Spiroplasma kunkelii; Spread
\end{abstract}

\section{Introduction}

Maize (Zea mayus) is a grass of the family Poaceae, Maydeae tribe, genus and specie Zea mays L. It is a crop of with international importance, occupying a prominent position among the agricultural species exploited worldwide, as it is a food of high energy value and, in a lower production cost, beyond be used in large numbers of by-products, it has more than 3500 uses directly and indirectly [1].

North America is the greatest producer of maize, but also worthy of mention are West and South America (Center of origin). The EUA, China and Brazil are responsible for $70 \%$ of the total volume of production of this crop [2]. In Brazil, it already is one the agricultural species of the greater importance, as relationship of crop area as production [3]. There is a predominance of maize crops in the Midwest and Southern regions of Brazil, which they represent near $68 \%$ cultivated area, and this are responsible for $76 \%$ of all production in national territory [1].
According Cota., et al. [3] among corn plant diseases in Brazil, deserve to be highlighted leaf spot or white spot (Pantoea ananas), the grey leaf spot (Cercospora zea-maydis), the Helminthosporium leaf spot and blight (Bipolaris maydis), the Southern (polysora) rust (Puccinia polysora), the Tropical rust (Physopella zeae), stalk rots (Fusarium spp., Diplodia spp., Colletotrichum among others), the Corn Stunt Phytoplasma ("Maize Bushy Stunt Phytoplasma") and the Maize Corn Stunt (Spiroplasma kunkelii). This last both plant diseases in recent years have caused greater yield losses in the Midwest of Brazil, in both summer and winter crop, It is causing and annual increase in the amount of inoculum in the field, consequently causing the survival of the population of the viruliferous vector leafhopper. Same results have been reported in others countries [4].

The corn leafhopper - Dalbulus maidis (DeLong and Wolcott) (Hemiptera: Cicadellidae), It's considered one pest main important of maize in Latin America. It can cause losses of up top to $100 \%$ by crop, depending on the infection season and maize hybrid [5]. In 
Brazil, the incidence of plant diseases by maize associated on Mollicutes increase considerably in last years, mainly in the southwest and Midwest regions [6]. Flight activity studies and flight behavior of $D$. maidis has indicated high potential of migration and dispersion of this specie by leafhopper [7].

The Maize Corn Stunt is caused by spiroplasma and the Maize Bushy Stunt by phytoplasma, both plant diseases prokaryotes infecting vascular system of plants, and belongs to a class Mollicutes [8]. This plant pathogen change the colors of the leaves also affect the development and production of grains, once the leaves are considered the main sources of photo-assimilates by corn, being the most important part of the plant [9]. The natural host single reported with Maize Corn Stunt (MCS) and Maize Bushy Stunt Phytoplasma (MBSP) are corn this moment and some Teosintes [5], but others grasses are host leafhopper.

It is postulated that these phytoplasmas survive this vector in seasons and that corn aren't cultivated, in others unknown and species leafhopper being be disseminated by long distance in and out of field [10].

The spatial spread of vector insect can be divided to three types: aggregate (or contagious), random or uniform (or regular) [11]. The spatial standard of MCS and MBSP in field generally express the dispersion process of pathogen [12]. Due to difficulty of detection by Mollicutes [13], and studying method of plant diseases, instead of vector, the recognition of spatial spread and temporal of corn stunt aren't describe in literature around the world.

The objective of this work was to perform a modelling and evaluate the spatial spread of corn stunt and choose the best model in different corn hybrids.

\section{Materials and Methods}

The experiment was held in the field 2016/2017, it implanted in Experimental Station RC Cruz, farm Esmeralda, address highway BR 050, (coordinates $17^{\circ} 29^{\prime} 31.35^{\prime \prime} 48^{\circ} 12^{\prime} 56.93^{\prime \prime}$ ) height: $908 \mathrm{~m}$, Ipameri, Goiás state, Brazil. The soil was characterized with being red yellow latosol dystrophic [14].

It was adopted no-tillage system being used 13 hybrids (Table 1) hybrids $1^{\odot}$, hybrids $2^{\odot}$, SHS $7920^{\circ}$, SH $7990^{\circ}$, DKB $177^{\circ}$, DKB $290^{\odot}, \mathrm{ADV} 9434^{\odot}, \mathrm{CD} 3612^{\odot}, \mathrm{CD} 3770^{\circ}$, NS $70^{\odot}$, NS $90^{\circ}$, NS $92 \mathrm{PRO}^{\odot}$ and AG 8070 PRO $3^{\odot}$. The technologies PRO e PRO3 refer transgenic hybrids, presenting resistance à armyworm (Spodoptera frugiperda), earworm (Helicoverpa zea) and drill-stalk (Diatraea saccharalis), and the last protein Bt exclusive by control of rootworm (Diabrotica speciosa) [15].

\begin{tabular}{|l|c|c|c|}
\hline Ord. & Companies & Maize Hybrids & Cycle \\
\hline 1 & Unknow & Hybrid1 & Unknow \\
\hline 2 & Unknow & Hybrid 2 & Unknow \\
\hline 3 & Santa Helena & SHS 7920 PRO PRO3 & Early \\
\hline 4 & Santa Helena & SHS 7990 PRO2 & Early \\
\hline 5 & Dekalb & DKB 177 PRO3 & Early \\
\hline 6 & Dekalb & DKB 2890 PRO3 & Early \\
\hline 7 & Advanta & ADV 9434 PRO & Early \\
\hline 8 & Coodetec & CD 3612PW & Early \\
\hline 9 & Coodetec & CD 3770PW & Early \\
\hline 10 & Nidera & NS 70 & Medium \\
\hline 11 & Nidera & NS 90 PRO PRO2 & Medium \\
\hline 12 & Nidera & NS 92 PRO PRO2 & Medium \\
\hline 13 & Sementes & AG 8070 PRO 3 & Early \\
\hline
\end{tabular}

Table 1: List of companies, commercial maize and cycle hybrids evaluated in this experiment.

The seeds were planted on 14/11/2016, cultivated in a randomized block design ( 6 blocks), being each block contain by 13 treatments (hybrids).

The experimental area cultivated with hybrids maize with dimensions of $4 \times 70 \mathrm{~m}$ (each block with $10 \mathrm{~m}$ of length) resulting one plants bulk organized on line spacing of $0,5 \mathrm{~m}$ and $0,2 \mathrm{~m}$ column spacing's a total eight crop lines. The sideways lines of each hybrids wasn't evaluable leaving only internal useful area by 6 growing line (30 m2.parcel-1) that they was referenced on three dimensions $\mathrm{X}$ $(\mathrm{m}), \mathrm{Y}(\mathrm{m})$ and $\mathrm{Z}$ that is one dependent variable was played by incidence MCS and MBSP, in a useful base area for $180 \mathrm{~m}^{2}$ producing spatial maps and temporal distribution and identification area in $\mathrm{m} 2$ with plant diseases incidence. It was considered symptoms by stunt corn [Maize Corn Stunt (MCS) and Maize Bushy Stunt Phytoplasma (MBSP)], the presence of stretch marks red to purple or yellow at the beginning on base of leaves, or in the leaves border.

It was evaluable the incidence of MCS and MBSP isolated by hybrids (ratio of number of symptoms plants by number of total plants [nt sample $=10$ meters]; borders of $2 \mathrm{~m}$ of line) by 95 days after planting (DAP) and 109 DAP. The measures of distance $X$ and Y, measured by meter, tt was associated by incidence by area and maize hybrid evaluable with stunt corn was analyzed in software of geostatistical Gamma Design GS+, and the spatial adjustment distributions by models Gaussian, Spherical, Linear and Exponential, creating adjustment model equation and graphics. The software STATISTICA ${ }^{\circledR}$ was utilized to represent for spatial incidence (distributions maps), being put values $\mathrm{x}, \mathrm{y}$ (spatial positions, $\mathrm{m}$ ) and $\mathrm{z}$ the incidence value of MCS and MBSP at 95 and 109 DAP. The spatial 
measures for $\mathrm{X}$ and $\mathrm{Y}$ was given in meters, and sanitary measure was released as a percentage of symptomatic plants, divided by a sample of 10 unit, was inserted by software in Gamma Design $\mathrm{GS}+\circledR$, that allowed to indicate adjusted semivariograms and spatial distributions model adjusted parameters calculated with the residual sum of squares (RSS). About graphics indications the RSS recognized the models, to explain better stunts corn disease in the different hybrids evaluated in the experiment.

\section{Results and Discussion}

Symptomatology of maize stunts

It was observed a higher visual incidence and damages of the MCS in the evaluated hybrids. Pereira [16] has pointed out that MCS is more frequent in outcrops and hot regions. Oliveira., et al. [6] pointed out a higher incidence of MCS (2-20\%) of incidence than MBSP (1-4\%) in greenhouse transmission bioassays.

Pereira [16] also highlighted these diseases as being major in the corn crop, pointing out that it is a serious problem in the Brazilian conditions of late planting, started from January. The spreading dynamics of the leafhopper were observed by the higher colonization and frequency of adult insects of the leafhopper on the apical leaves, transmitting the disease in this part, logically distributing systemically to all the organs of the aerial part. Gussie., et al. [17] pointed out that when infecting corn seedlings, the Spiroplasma moves first towards the roots and then towards the shoot. There is a greater preference of the insect vector, due to ease of mechanical penetration in the young tissues, and these represent the gateway to colonization in the plant [8].

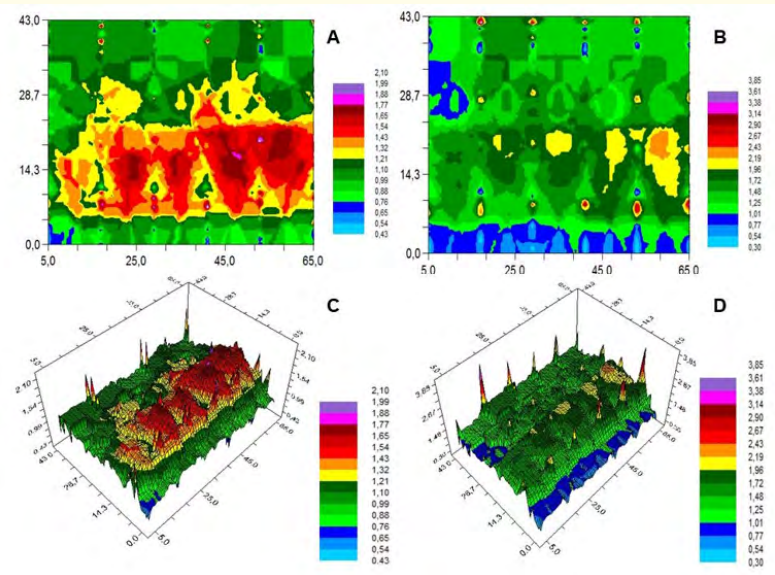

Figure 1: Spatial spread of Maize Corn Stunt (Spiroplasma kunkelii) in maize (Zea mays) at 95 and 109 days after planting (DAP). A. 2D spread at 95 DAP, B. 2D spread at 109 DAP, C. 3D spread at 95 DAP, D. 3D spread at 109 DAP.
Another observed effect, due to the presence of the two maize stunts, is the reduction and failure of ear production, shortening of internodes. Pereira [16] pointed out that plants infected by Phytoplasma may have a higher number of ears that do not produce grains. The plants presented symptoms of shortening of internodes, consequently characterized as dwarfism.

\section{MCS spread}

At the 95 DAP level (approximately in R3), the incidence of MCS reached an aggregate pattern (higher incidence) ranging from $0.43 \%$ to $2.10 \%$ in the evaluation area of the maize hybrids (Figure 1A). At the 109 DAP (approximately R5 cycle), the incidence followed the same pattern in the amplitude, but in a greater amplitude of incidence $0.3-3.85 \%$ incidence in the evaluated area (Figure 1B).

\section{MCS spread}

Spatially at 95 DAP in the range of incidence of MBSP reached an isolated or aggregate pattern (located at the borders) ranging from $0.02 \%$ to $5.16 \%$ (range greater than the MCS) of incidence in the area of maize hybrids (Figure 2A). Silva., et al. [11], when analyzing the spatial pattern of spreading, not of the disease, but of the leafhopper (Empoasca kraemeri) also observed an aggregate pattern in string bean, demonstrating a relationship of the distribution pattern of the disease with the insect vector. At 109 DAP (approximately R5), the incidence followed the same pattern of temporal amplitude of $0.11-4.78 \%$ incidence in the evaluated area (Figure 2B).

Hybrids located on the edges of the experimental area had the highest spatial incidences of the disease (except for a few isolated spots) (Figure $2 \mathrm{AB}$ ).

When comparing the peaks of incidence of MBSP at 95 and 109 DAP, there was an area of greater number of foci of the disease at 95 DAP (Figure 2C) than at 109 DAP (Figure 2D), being located on the edges of the experimental area.

At 95 DAP, the number of peaks with the highest incidence of MBSP, which would represent the sources of onset of the epidemic in the area, was 11 peaks (Figure 2C), while at 109 DAP was eight peaks (Figure 2D).

\section{Adjustment models of MCS and MBSP by cultivar}

Four models explained the spatial spread of MCS at 95 and 109 DAP. At 95 DAP were represented by the spherical for Hybrid 1, SH $7990^{\odot}, \mathrm{ADV} 9434^{\odot}$ and NS 70॰${ }^{\circ}$; the Exponential model for Hybrid 2, CD $3770^{\odot}$ and NS 92 PRO; the Linear model for the hybrid SH 


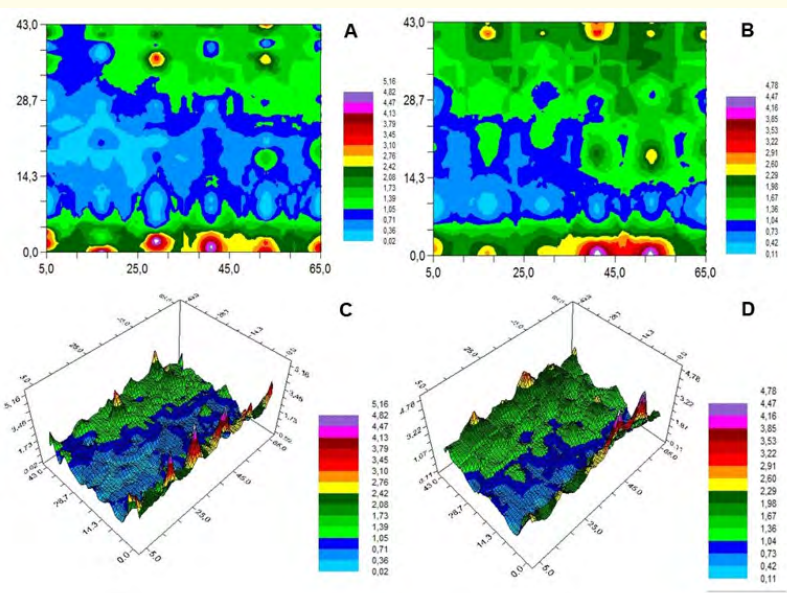

Figure 2: Spatial spread of Maize Bushy Stunt Phytoplasma in maize (Zea mays) at 95 and 109 days after planting (DAP). A. 2D spread at 95 DAP, B. 2D spread at 109 DAP, C. Density spread at 95 DAP, D. Density spread at 109 DAP. $7920^{\odot}, \mathrm{CD}^{3612^{\odot}}$ and AG 8070 PRO $3^{\odot}$; and the Gaussian model for the hybrid DKB $177^{\circledR}$, NS $90^{\circledR}$ and DKB $290^{\circledR}$ (Table 2). At 109 DAP were represented by spherical SH7920 ${ }^{\circledR}$, DKB $177^{\circledR}$, DKB $290^{\circledR}, \mathrm{CD}$ $3770^{\circledR}, \mathrm{ADV} 9434^{\circledR}$ and NS $70^{\circledR}$; and the Exponential model for Hybrid 2; the Linear model for SH $7990^{\circ}$, CD $3612^{\circ}$, NS $90^{\circ}$ hybrid and AG 8070 PRO $3^{\circ}$; and the Gaussian model for Hybrid 1 and NS 92 PRO (Table 2).

The spatial spread at 95 DAP was better explained for hybrids 1 and DKB 177@ and 109 DAP for the hybrid NS 92 PROC, because they presented more points within the model ("line"). The other hybrids presented one or several discrepant values devaluated by this visual and graphical analysis strategy the best model adjusted and indicated to explain the spatial spread of the mating.

The residual sum of squares (RSS) devalues some better Adjustment models for the MCS at 95 DAP. The three best and worst adjusted hybrids (the incidence of the disease was best explained by the proposed model for the spatial spread), respectively, were

\begin{tabular}{|c|c|c|c|c|c|c|c|c|}
\hline \multirow{3}{*}{$\begin{array}{c}\text { Commercial } \\
\text { hybrids }\end{array}$} & \multicolumn{4}{|c|}{ Maize Corn Stunt (Spiroplasma kunkelii) } & \multicolumn{4}{|c|}{ Maize Bushy Stunt Phytoplasma } \\
\hline & \multicolumn{2}{|c|}{95 DAP } & \multicolumn{2}{|c|}{109 DAP } & \multicolumn{2}{|c|}{95 DAP } & \multicolumn{2}{|c|}{109 DAP } \\
\hline & $\begin{array}{c}\text { Adjustment } \\
\text { model }\end{array}$ & SRS & $\begin{array}{c}\text { Adjustment } \\
\text { model }\end{array}$ & RSS & $\begin{array}{c}\text { Adjustment } \\
\text { model }\end{array}$ & RSS & $\begin{array}{l}\text { Adjustment } \\
\text { model }\end{array}$ & RSS \\
\hline ADV $9434^{\circ}$ & Spherical & 11,9000 & Spherical & 23,2000 & Spherical & 0,0014 & Linear & 0,0174 \\
\hline $\begin{array}{l}\text { AG } 8070 \text { PRO } \\
3^{\odot}\end{array}$ & Linear & 0,2690 & Linear & 0,0009 & Linear & 3,7700 & Linear & 185,0000 \\
\hline CD $3612^{\odot}$ & Linear & 0,0096 & Linear & 0,0633 & Gaussian & 0,0007 & Gaussian & 0,0007 \\
\hline $\mathrm{CD} 3770^{\circ}$ & Exponential & 1,2900 & Spherical & 1,0300 & Linear & 0,2100 & Exponential & 2,4700 \\
\hline DKB $177^{\circ}$ & Gaussian & 0,1940 & Gaussian & 0,0007 & Spherical & 0,0084 & Exponential & 0,1090 \\
\hline DKB $290^{\circ}$ & Gaussian & 11,0000 & Exponential & 0,0219 & Gaussian & 0,0007 & Linear & 0,0009 \\
\hline Híbrido 1 & Spherical & 0,0000 & Spherical & 0,5080 & Gaussian & 29,6000 & Spherical & 87,1000 \\
\hline Híbrido 2 & Exponential & 0,0166 & Spherical & 48,0000 & Spherical & 17,1000 & Gaussian & 12,7000 \\
\hline NS $70^{\odot}$ & Spherical & 0,3650 & Spherical & 4,9700 & Gaussian & 0,0098 & Spherical & 0,2840 \\
\hline NS $90^{\circ}$ & Gaussian & 0,0767 & Linear & 0,0158 & Spherical & 2,5300 & Spherical & 4,1000 \\
\hline NS 92 PRO & Exponential & 1,7900 & Gaussian & 3,2000 & Spherical & 5,8200 & Linear & 0,0136 \\
\hline SH $7920^{\circ}$ & Linear & 0,0336 & Spherical & 0,0539 & Spherical & 5,8200 & Spherical & 2,5100 \\
\hline SH $7990^{\circ}$ & Spherical & 6,7800 & Linear & 1,3700 & Linear & 7,1200 & Spherical & 4,3500 \\
\hline
\end{tabular}

Table 2: Adjustment model and the residual sum of squares (RSS) for the MCS and MBSP of commercial maize hybrids at 95 days after planting (DAP) and 109 DAP*.

* Parameters marked in bold represent the best models of adjusted semivariograms; parameters marked in underscore represent the worst models of semivariograms adjusted. 
hybrid 1 (Spherical), hybrid 2 (Exponential) and CD 3612 ${ }^{\odot}$ (Linear); and SH 7990 (spherical), DKB 290 (Gaussian) and ADV 9434 (Spherical) (Table 2). For the MCS at 109 DAP, the three best and worst adjusted hybrids (the incidence of the disease was best explained by the proposed model for the spatial spread), respectively, were hybrids 1 (Gaussian), AG 8070 PRO $3^{\odot}$ (Linear) and NS 90 ${ }^{\circledR}$ (Linear); DKB $290^{\circledR}$ (Spherical), ADV $9434^{\circledR}$ (Spherical) and NS 70 ${ }^{\circledR}$ (Spherical) (Table 2). The most frequent model in corn hybrids evaluated at 95 and 109 DAP was the spherical model, independent of being more adjusted by the parameters (Table 2).

Three models explained the spatial spread of MBSP at 95 DAP being represented by the Spherical for Hybrid 2, SH $7920^{\circ}$, DKB $177^{\odot}, \mathrm{ADV} 9434^{\odot}$, NS $90^{\circ}$ and NS 92 PRO; the Linear model for the hybrid $\mathrm{SH} 7990^{\odot}, \mathrm{CD} 3770^{\odot}$ and AG 8070 PRO $3^{\odot}$; and the Gaussian model for Hybrid 1, DKB $290^{\circ}, \mathrm{CD}_{3612^{\odot}}$ and NS $70^{\odot}$ (Table 2). Four models explained the spatial spread at 19 DAP of MBSP, being represented by the Spherical for Hybrid 1, SH 7920 ${ }^{\circ}$, SH $7990^{\circ}$, NS $70^{\odot}$ and NS $90^{\circ}$; the Exponential model for DKB $177^{\circ}$ and CD $3770^{\circ}$; the Linear model for hybrid DKB 290 ${ }^{\circ}$, ADV 9434 ${ }^{\circ}$, NS 92 $\mathrm{PRO}^{\odot}$ and $\mathrm{AG} 8070$ PRO $3^{\odot}$; and the Gaussian model for Hybrid 2, CD3612 (Table 2).

The spatial spread of MBSP at 95 DAP was better explained for the DKB $177^{\odot}$ and NS $70^{\odot}$ hybrids, and at 109 DAP, for hybrids 2 and DKB $177^{\odot}$ (Table 2), because they presented higher number of points within the model ("line"). The other hybrids presented one or several discrepant values devaluated, by this visual and graphical analysis strategy, the best model adjusted and indicated to explain the spatial spread of the maize stunt.

The residual sum of squares (RSS) devalued some better Adjustment models for MBSP at 95 and 109 DAP (Table 2). The three best and worst hybrids adjusted to 95 DAP respectively were hybrids DKB 290 (Gaussian), ADV 9434 (Spherical) and CD 3612 (Gaussian); Hybrid 1 (Gaussian), Hybrid 2 (Spherical) and SH 7990 (Linear) (Table 2).

For the MBSP at 109 DAP the three best and worst adjusted hybrids, respectively, were hybrids CD 3612 (Gaussian), DKB 290 (Linear) and NS 92 PRO (Linear); AG 8070 PRO $3^{\odot}$ (Linear), Hybrid 1 (Spherical) and Hybrid 2 (Gaussian) (Table 2).

The most frequent model in corn hybrids evaluated at 95 and 109 DAP was the spherical model, independent of being adjusted for the presence of discrepant value and RSS (Table 2).

\section{Discussion}

\section{Symptomatology of maize stunts}

Oliveira., et al. [6] when studying corn viruses and stunts showed that diseases caused by Mollicutes had more important diseases than corn virus in the PR. Cota., et al. [3] pointed out that the late planting conditions increase the amount of inoculum in the field, allowing the survival of the population of $D$. maidis in this period, since it coincides with the longer period of infestation of the leafhopper.

It is recognized that the prokaryotes that were transmitted by the viruliferous leafhoppers (capable of transmitting the phytopathogen) [18] fed the hybrids evaluated, and that from the sucking activity of the leafhopper, allowed the long-distance transmission of these bacteria with the vascular system (xylem and phloem) allowing systemic spreading, with the young leaves being the source of inoculum arrival. The leafhopper has a migratory habit and disseminates the maize crops from diseased maize to young seedlings from newly established crops [10]. There is a preference and migration of leafhoppers from old plants to younger seedlings transmitting pests [16]. The prokaryote ("Maize Bushy Stunt Phytoplasma") as a result of its colonization provokes plastic symptom of anthocyanin production causing purpura of the leaf blade. This MBSP can provoke symptoms in the limb or the veins, in the low leaves and apical leaves, not establishing patterns of appearance of symptoms connected to the age of the organ or plant, as widely cited for white-spot-of-the-corn, diplodia-leaf-spot, helminthosporium-leaf-spot-and-blight by Pereira [16].

\section{MCS spread}

The incidence peaks of the disease would be the sources of viruliferous leafhoppers (containing the prokaryotes) arrivals where they produced inoculum sources influenced by varietal susceptibility. The resistance to stunts is determined by the number of infected plants (incidence) and not by the level of resistance of infected plants (severity) [19].

Due to the higher concentrations or peaks of incidence following the hybrid's growth range, the genetic component of response to the disease explained the standardized concentrations, that is, the spreading and dissemination were more dependent on the susceptibility of the cultivar than the infectivity of the insect vector, since the hybrids located on the edges of the experimental area presented the smallest spatial incidences of the disease (except for a few isolated spots) (Figure $1 \mathrm{AB}$ ). The spread of the disease was linked to the vector from "within" the evaluated area. 
Regarding the genetics of mating resistance, Silva., et al. [19], in Brazil, showed that they were resistant to genetic diseases as C 333B (single, normal, semi-solid, and semi-hybrid), and P3041 (triple, early cycle, planting late).

\section{MBSP spread}

In order to differentiate the two evaluation days (95 and 109 DAP), an increase in the spatial incidence was observed at the largest coordinates of the $\mathrm{Y}$ axis towards the smaller coordinates of the $\mathrm{X}$ axis (Figure 2CD), where the incidence peaks would be the sources of viruliferous leafhoppers, capable of producing sources of inoculum for dissemination.

Due to the higher concentrations or peaks of incidence being located on the edges of the experimental area, they coincide with the probable arrival and attack sites of the corn leafhopper, not being represented by a genetic component, as was recognized for red nesting (Figure 2).

The genetic component of response to the incidence of the disease did not explain the peaks of red stunting in the marginal regions, that is, the spreading and dissemination depended on the arrival of the vector insects coming from "outside" the plant population.

Nault [5] points out instability in genetic reactions in which the symptomatic variations are dependent on the genetic component (genotype) and climatic conditions (environment) on the hybrids. However, Bustamante [20] selected 2980-93 and 3974 accessions, as presenting slow and late symptoms of "Maize rayado fino virus" - phytopathogen also transmitted by the leafhopper.

\section{Adjustment models of MCS and MBSP by cultivar}

The adjustment models presented differential behavior by hybrids, that is, the mathematical modelling to explain the spatial spread of MCS and MBSP at 95 and 109 DAP was different and influenced by discrepant values.

At 95 DAP it became evident that there is no standard model to explain the spatial spread of MCS. At 109 DAP there was a linear model trend for the hybrids best fitted to explain the spatial distribution of MCS.

For MCS there was a trend of the Gaussian model for the hybrids best fitted to the 95 DAP. At 109 DAP there was a trend to the linear model for the best fit hybrids to explain the spatial spread of MBSP.

Even with the best adjustments for each hybrid, a more frequent model was found in all the cultivars for MCS and MBSP, showing that there is no specific model capable of explaining the distribution of the disease in all the scenarios.

\section{Conclusion}

The peaks of incidence of the MCS and MBSP presented a system of differentiated dissemination in the culture. It is assumed that the sources of inoculum of the MCS were present within the plot, and were influenced by the genetic component of the hybrid. For the MBSP, the source of inoculum is supposed to have come from outside, influenced by the population of the leafhopper vector in the plot of evaluated hybrids.

Regardless of the best adjustment parameters, the most frequent model that explains the spatial spread of the MCS and MBSP on the evaluated days was the spherical model.

\section{Summary}

In recent years, there have been advances in the outbreaks of pale and red stunting in maize (Zea mays) crops, probably due to the increase in the spittle population. The objective was to perform a modeling and to evaluate the spatial distribution of the pale and red enfezamiento in different commercial hybrids of corn cultivated in the crop of 2017. The experiment was carried out with 13 hybrids, in the municipality of Ipameri, GO. The experimental area per hybrid showed the dimensions of $4 \times 70 \mathrm{~m}$ and $10 \mathrm{~m}$ in length, resulting in a population of plants organized in a spacing of $0.5 \mathrm{~m}$ and distance between plants of $0.2 \mathrm{~m}$ sown in eight growing lines. The lines were referenced in the $\mathrm{X}$ and $\mathrm{Y}$ axis, with the pale and red enfezamiento incidence, referenced by $\mathrm{Z}$ in a useful area per hybrid of $210 \mathrm{~m}^{2}$ for modeling and construction of spatial distribution maps. There was a significant difference between the geographic distance and the incidence of both types of moths. The adjustment models recognized for the pale and red haunches by cultivar were the Spherical, Exponential, Linear and Gaussian, being the most frequent model to explain the spatial distribution of both enfezamientos was the Spherical.

\section{Bibliography}

1. Môro GV and FRITSCHE-NETO R. Importância e usos do milho no Brasil. In: BOREM, A.; GALVAO, J.C.C.; PIMENTEL, M.A. Milho do plantio à colheita. Viçosa: Ed. UFV (2015).

2. ESTADOS UNIDOS. Department of Agriculture. USDA.gov United States Department of Agriculture (2017).

3. Cota LV., et al. "Manejo de doenças". In: BOREM, A.; GALVAO, J.C.C; PIMENTEL, M.A. Milho do plantio à colheita. Viçosa: Ed. UFV (2015). 
4. Hruska AJ and PERALTA MG. "Maize response to corn leafhopper (Homoptera: Cicadellidae) infestation and achaparramiento disease". Journal of Economic Entomology 90 (1997): 604-610.

5. Nault LR. "Evolution of insect pest: maize and leafhopper, a case study”. Maydica 35 (1990): 165-175.

6. Oliveira E., et al. "Incidência de viroses e enfezamentos e estimativa de perdas causadas por molicutes em milho no Paraná". Pesquisa agropecuária brasileira, Brasília 38.1 (2003): 19-25.

7. Taylor RAJ., et al. "Experimental analysis of flight activity of three Dalbulus leafhoppers (Homoptera: Auchenorrhyncha) in relation to migration". Annals of the Entomological Society of America 86 (1993): 655-667.

8. Balmer E. "Doenças do milho". In: GALLI, F. (Coord.). Manual de fitopatologia: doenças das plantas cultivadas. São Paulo: Agronômica Ceres (2016): 371-391.

9. Magalhães PC., et al. Fisiologia da planta de milho. Sete Lagoas, EMBRAPA-CNPMS, (1995): 27.

10. Oliveira CM., et al. "Disseminação de molicutes do milho a longas distâncias por Dalbulus maidis (Hemiptera: Cicadellidae)". Fitopatologia Brasileira 27 (2002): 091-095.

11. Silva V., et al. "Distribuição espatial da cigarrinha Empoasca kraemeri Ross and Moore (Hemiptera: Cidadelidade) no feijão de corda e cálculo do número de amostras". Arquivos do Instituto Biológico 81.4 (2014): 335-341.

12. Hau B., et al. "Epidemiologia: análise spatial”. In: KIMATI, H.; AMORIM, L.; REZENDE, J. A. M.; BERGAMIN FILHO A., CAMARGO, L. E. A. Manual de Fitopatologia 1 (2011).

13. Barros TSL., et al. "Design of a polymerase chain reaction for specific detection of corn stunt spiroplasma". Plant Disease 85 (2001): 475-480.

14. EMBRAPA - CNPS. Sistema Brasileiro de Classificação de Solos. Brasilia: Embrapa-SPI; Rio de Janeiro: Embrapa-Solos, (2013).

15. Fristche-Neto R and MÔRO GV. "Cultivares". In: BOREM, A.; GALVAO, J.C.C; PIMENTEL, M.A. Milho do plantio à colheita. Viçosa: Ed. UFV, (2015).
16. Pereira OAP. "Doenças do milho". In: KIMATI, H.; AMORIM, L.; REZENDE, J. A. M.; BERGAMIN FILHO, A.; CAMARGO, L. E. A. Manual de Fitopatologia. São Paulo: Agronômica Ceres, (2011).

17. Gussie JS., et al. "Movement and multiplication of Spiroplasma kunkelii in corn". Phytopathology 85 (1995): 1093-1098.

18. Agrios GN. Plant pathology. 4a Ed., Academic Press. (2005): 606.

19. Silva RG., et al. "Controle genético da resistência aos enfezamentos de milho". Pesquisa Agropecuária Brasileira 38 (2003): 921-928.

20. Bustamante PI., et al. "Evaluation of maize germ plasm for resistance to maize rayado fino virus". Plant Disease 82 (1998): 50-56.

Volume 3 Issue 8 August 2019

(C) All rights are reserved by Erica de Castro Costa., et al. 